\title{
Perbedaan Rerata Kadar Progesterone-Induced Blocking Factor (PIBF) Serum Penderita Abortus Iminens dengan Kehamilan Normal
}

\author{
Defrin $^{1}$, Andri Ardinal ${ }^{1}$, Erkadius $^{2}$
}

\begin{abstract}
Abstrak
Progesterone-Induced Blocking Factor (PIBF) merupakan suatu mediator yang diproduksi oleh limfosit wanita hamil yang telah mengalami sensitisasi oleh progesterone, yang menyebabkan terjadinya toleransi terhadap antigen paternal sehingga dapat menekan produksi sitokin-sitokin Th-1 yang bersifat sitotoksis terhadap kehamilan. Tujuan penelitian ini adalah membandingkan antara rerata kadar PIBF serum penderita abortus iminens dan kehamilan normal usia kehamilan 12-20 minggu. Studi ini dilakukan dengan metode analitik observasional dengan desain crosssectional comparative. Subjek penelitian adalah wanita hamil yang datang ke poliklinik dan IGD kebidanan rumah sakit Dr.M.Djamil Padang, RSUD Bukittinggi, RSUD Painan, RSUD Batusangkar, RSUD Pariaman dan RSUD Solok pada periode Mei 2016 sampai September 2016. Pemeriksaan kadar PIBF dilakukan di Laboratorium biomedik FK UNAND. Total sampel adalah 30 orang, yang dibagi menjadi 2 kelompok yaitu 15 orang pada kelompok abortus iminens dan 15 orang pada kelompok kehamilan normal. Analisis statistik untuk menilai kemaknaan menggunakan unpaired t-test. Didapatkan rerata kadar PIBF serum penderita abortus iminens $(623.3 \pm 80.6 \mathrm{ng} / \mathrm{ml})$ lebih rendah secara signifikan dibandingkan dengan kehamilan normal $(993.1 \pm 68.5 \mathrm{ng} / \mathrm{ml})(p=0.000)$. Simpulan penelitian ini adalah kadar PIBF serum penderita abortus iminens lebih rendah dibandingkan kehamilan normal.
\end{abstract}

Kata kunci: abortus iminens, serum, progesterone-induced blocking factor

\section{Abstract}

Progesterone-Induced Blocking Factor (PIBF) is a mediator produced by lymphocytes of pregnant women which have undergone sensitization by progesterone, which is this mediator can induced the tolerance to paternal antigens that can suppressing the production of cytokines Th-1 that are cytotoxic against pregnancy. The objective of this study was to compare between concentration of serum PIBF in threatened abortion patient and normal pregnancy at 12-20 weeks of gestational age. This research was a comparative cross sectional study. The study was conducted at the Obgyn clinic and emergency room of Dr. M. Djamil Hospital Padang, Bukittinggi District Hospital, Painan District Hospital, Batusangkar District Hospital, Pariaman District Hospital, Solok District Hospital and Biomedical Laboratory Andalas University between May 2016 until September 2016. Total sample was 30, which divided into two group; a group of 15 women with threatened abortion and a group of 15 women with normal pregnancy. Statistic analysis was done by unpaired t-test. The result of this research is PIBF concentration in serum of threatened abortion patient $(623.3 \pm 80.6 \mathrm{ng} / \mathrm{ml})$ were significantly lower than normal pregnancy $(993.1 \pm 68.5 \mathrm{ng} / \mathrm{ml})(p=0.000)$. So in conclusion, women with threatened abortion had significantly lower serum PIBF concentration compared with normal pregnancy. Keywords: threatened abortion, serum, progesterone-induced blocking factor

Affiliasi penulis: 1. Bagian Obstetri dan Ginekologi FK Unand (Fakultas Kedokteran Universitas Andalas/RSUP Dr.M.Djamil Padang, 2. Bagian Fisiologi FK Unand.
Korespondensi: Defrin, Email:defrin_pdg@yahoo.com, Telp: 08126722886 


\section{PENDAHULUAN}

Wanita hamil dihadapkan pada berbagai komplikasi yang mungkin terjadi, salah satunya adalah abortus. Abortus adalah kejadian berakhirnya kehamilan secara spontan maupun diinduksi sebelum janin viable. Peristiwa ini adalah komplikasi yang cukup sering terjadi yaitu $15-20 \%$ dari seluruh kehamilan. Sekitar $80 \%$ abortus spontan terjadi pada trimester pertama; insidennya berkurang seiring dengan bertambahnya usia kehamilan. Abortus spontan di Indonesia diperkirakan sekitar 10\% - 15\% dari 6 juta kehamilan setiap tahunnya atau sekitar 600 900 ribu. Jika tidak berakhir dengan kematian janin, maka kehamilan ini akan beresiko untuk terjadinya persalinan preterm, IUFD dan berat badan lahir rendah. $^{1}$

Etiologi dari abortus sangat beragam, seperti genetik, anatomis, endokrin, imunologis, infeksi, trombofilik dan idiopatik. Sebagian dari etiologi imunologis ini bisa diakibatkan oleh respon imun maternal yang bersifat merusak terhadap fetus. Faktor imunologis dapat menyebabkan abortus melalui mekanisme autoimun; yaitu imunitas terhadap diri sendiri dan alloimun; yaitu imunitas terhadap orang lain. Berdasarkan teori alloimun, suatu kehamilan agar berhasil membutuhkan adanya blocking factor yang dapat menghambat penolakan sistem imun maternal terhadap antigen paternal. ${ }^{2}$

Berbagai penelitian menunjukkan bahwa progesteron berperan dalam menciptakan lingkungan imun yang adekuat selama awal kehamilan. Progesterone-Induced Blocking Factor (PIBF) merupakan suatu mediator yang diproduksi oleh limfosit wanita hamil yang telah mengalami sensitisasi oleh progesteron. Mediator ini akan menyebabkan terjadinya toleransi terhadap antigen paternal. Toleransi terhadap kehamilan terjadi dengan menekan produksi sitokin-sitokin Th-1 yang bersifat sitotoksis terhadap kehamilan, meningkatkan produksi antibodi asimetris yang bersifat protektif serta dengan menekan aktifitas sel Natural Killer. ${ }^{3}$

PIBF dapat dideteksi pada darah dan urin wanita hamil. Penelitian Polgar et al (2004), pada 582 wanita hamil menunjukkan bahwa kadar PIBF urin pada wanita hamil normal terus meningkat mulai usia kehamilan tujuh minggu hingga usia kehamilan 37 minggu. Setelah usia kehamilan 41 minggu, konsentrasi PIBF akan menurun secara drastis. Pada kehamilan patologis, tidak terjadi peningkatan kadar PIBF. ${ }^{4}$

Salomon et al (2005) di Perancis, meneliti tentang ekspresi PIBF oleh limfosit perifer pada wanita hamil normal setelah pemberian mifepristone untuk terminasi kehamilan non-surgikal pada usia kehamilan 5-8 minggu. Pada 17 dari 21 pasien, persentase limfosit dengan PIBF positif menurun setelah pemberian anti progesterone. Persentase limfosit yang meng-ekspresikan PIBF menurun secara bermakna dari $52,8 \% \pm 21,6 \%$ (hari 0 ) menjadi $39,8 \% \pm 18,2 \%$ (hari 2). Kadar progesteron plasma juga dihitung, dan tidak terdapat perubahan bermakna selama pemberian mifepristone. Hasil ini menunjukkan kemungkinan terlibatnya PIBF dalam terminasi kehamilan yang diinduksi dengan mifepristone pada kehamilan dini, didukung pula dengan tidak berubahnya kadar progesteron selama periode ini. PIBF diproduksi setelah progesteron berikatan dengan reseptornya, dengan demikian mifepristone berkemungkinan mengurangi produksi PIBF dengan menghambat progesteron reseptor. Hal ini nantinya berdampak terhadap dominasi sitokin Th-1 dan meningkatkan aktivitas sel NK yang berakhir dengan abortus. ${ }^{5}$

Penelitian Kalinka dan Szekeres-Bartho (2005), pasien abortus iminens yang diberikan progestogen dibandingkan dengan kehamilan normal. Pada penelitian ini didapatkan bahwa pemberian progestogen tidak meningkatkan kadar progesteron darah pada kelompok abortus iminens. Namun, pemberian progestogen ini meningkatkan kadar PIBF kelompok abortus, sampai kadar yang tidak berbeda secara statistik dengan kelompok hamil normal. Outcome kedua kelompok pada penelitian ini juga menunjukkan perbedaan yang tidak signifikan. Penelitian ini memberikan gambaran bahwa pemberian progestogen mempengaruhi fungsi progesteron dengan tidak mempengaruhi kadar progesterone. $^{6}$

Hudic dan Fatusic (2009), meneliti kadar PIBF pada awal kehamilan. Pada penelitian yang melibatkan 20 wanita hamil normal dan 30 wanita dengan abortus iminens pada usia kehamilan 6-24 minggu ini, didapatkan bahwa kadar PIBF pada serum 
wanita dengan abortus iminens $(214,4 \pm 120,6 \mathrm{ng} / \mathrm{ml})$ yang lebih rendah dibandingkan wanita hamil normal $(357,0 \pm 159,9 \mathrm{ng} / \mathrm{ml})$. Dengan memeriksa kadar PIBF pada urin, didapatkan pula hasil yang serupa $(19,5 \pm 12,9 \mathrm{ng} / \mathrm{ml}$ pada abortus iminens ; 45,3 $\pm 33,7$ $\mathrm{ng} / \mathrm{ml}$ pada hamil normal). Dengan nilai potong 182,8 $\mathrm{ng} / \mathrm{ml}$ untuk kadar PIBF serum, didapatkan prediksi terminasi kehamilan dengan sensitifitas 53\%, spesifisitas $95 \%$, positive predictive value $94 \%$ dan negative predictive value $95 \% .^{2}$ Berdasarkan latar belakang diatas, perlu dilakukan penelitian mengenai perbedaan rerata kadar PIBF antara penderita abortus iminens dan kehamilan normal.

\section{METODE}

Penelitian ini dilakukan dengan metode comparative cross-sectional. Penelitian ini dilakukan pada wanita hamil yang datang ke poliklinik dan IGD kebidanan rumah sakit Dr. M. Djamil Padang, RSUD Bukittinggi, RSUD Painan, RSUD Batusangkar, RSUD Pariaman dan RSUD Solok pada periode Mei 2016 sampai September 2016. Pemeriksaan kadar PIBF dilakukan di Laboratorium biomedik FK UNAND. Bahan yang diambil untuk diteliti berupa darah vena perifer dan untuk mengukur kadar PIBF yang ada dalam darah menggunakan metode ELISA. Total sampel adalah 30 orang, yang dibagi menjadi 2 kelompok yaitu 15 orang pada kelompok abortus iminens dan 15 orang pada kelompok kehamilan normal. Analisis statistik untuk menilai kemaknaan menggunakan unpaired t-test.

\section{HASIL}

\section{a. Karakteristik Sampel Penelitian}

Dari 30 sampel yang memenuhi kriteria inklusi dan eksklusi didapatkan karakteristik sampel penelitian berdasarkan usia, gravida, usia kehamilan dan riwayat abortus seperti yang terlihat pada Tabel 1 dan 2.

Berdasarkan karakteristik usia responden pada Tabel 1 didapatkan rerata usia kelompok penderita abortus iminens lebih rendah dibandingkan dengan rerata usia pada kelompok hamil normal didapatkan $28.2 \pm 3.6$ tahun : $28.9 \pm 5.5$ tahun. Secara statistik perbedaan tersebut tidak bermakna, terlihat nilai $p=$
0.698 ( $p>0,05)$. Hal ini menunjukkan bahwa usia pada penderita abortus iminens setara dengan kehamilan normal.

Tabel 1. Karakteristik sampel penelitian

\begin{tabular}{llll}
\hline \multirow{2}{*}{ Karakteristik } & \multicolumn{2}{l}{ Kelompok } & \multirow{2}{*}{$\mathbf{p}$} \\
\cline { 2 - 3 } & Abortus & Hamil normal & \multirow{2}{*}{$\mathbf{p}$} \\
\cline { 2 - 3 } & (Mean \pm SD) & (Mean \pm SD) & \\
\hline Usia & $28.2 \pm 3.6$ & $28.9 \pm 5.5$ & 0.698 \\
Gravida & $2.3 \pm 1.5$ & $2.3 \pm 1.4$ & 1.00 \\
Usia Kehamilan & $15.4 \pm 2.4$ & $13.8 \pm 2.1$ & 0.065 \\
\hline
\end{tabular}

Berdasarkan karakteristik gravida pada Tabel 1 didapatkan nilai rerata gravida kelompok penderita abortus iminens setara dengan dengan nilai rerata gravida pada kelompok hamil normal didapatkan $2.3 \pm$ $1.5: 2.3 \pm$ 1.4. Secara statistik tidak terdapat perbedaan bermakna, terlihat dari nilai $p=1.00$ $(p>0,05)$. Hal ini menunjukkan bahwa gravida pada penderita abortus iminens setara dengan kehamilan normal.

Karakteristik usia kehamilan didapatkan nilai rerata usia kehamilan penderita abortus iminens lebih tinggi dibandingkan dengan nilai rerata usia kehamilan pada kelompok hamil normal didapatkan $15.4 \pm 2.4$ minggu : $13.8 \pm 2.1$ minggu. Secara statistik perbedaan tersebut tidak bermakna, terlihat dari nilai $p=0.065 \quad(p>0,05)$. Hal ini menunjukkan bahwa usia kehamilan pada penderita abortus iminens setara dengan kehamilan normal.

Tabel 2. Karakteristik riwayat abortus

\begin{tabular}{|c|c|c|c|c|c|}
\hline \multirow{3}{*}{ Karakteristik } & \multicolumn{4}{|c|}{ Kelompok } & \multirow{3}{*}{$\mathbf{p}$} \\
\hline & \multicolumn{2}{|c|}{ Abortus } & \multicolumn{2}{|c|}{$\begin{array}{l}\text { Hamil } \\
\text { normal }\end{array}$} & \\
\hline & f & $\%$ & $f$ & $\%$ & \\
\hline \multicolumn{6}{|c|}{ Riwayat Abortus } \\
\hline Ada & 2 & 13.3 & 2 & 13.3 & \\
\hline Tidak ada & 13 & 86.7 & 13 & 86.7 & 0.402 \\
\hline \multicolumn{6}{|c|}{$\begin{array}{l}\text { didapatkan jumlah responden yang memiliki riwayat } \\
\text { abortus pada kehamilan normal sama dengan pada } \\
\text { penderita abortus yaitu } 2 \text { orang }(13.3 \%) \text {. Hasil analisis }\end{array}$} \\
\hline
\end{tabular}


penderita abortus iminens dengan kehamilan normal tidak memiliki perbedaan yang bermakna, hal ini terlihat dari nilai $p 0.402(p>0,05)$.

\section{b. Kadar PIBF Serum Penderita Abortus Iminens} Dengan Kehamilan Normal.

Tabel 3. Rerata kadar PIBF serum

\begin{tabular}{llll}
\hline & $\begin{array}{l}\text { Abortus } \\
\text { Iminens } \\
\mathbf{n}=15\end{array}$ & $\begin{array}{l}\text { Hamil } \\
\text { Normal } \\
\mathbf{n}=15\end{array}$ & $\mathbf{p}$ \\
\hline $\begin{array}{l}\text { Kadar } \\
\text { (ng/mI) }\end{array}$ & PIBF & & \\
$\begin{array}{l}\text { Mean } \\
\text { SD }\end{array}$ & 623.3 & 993.1 & \\
& 80.6 & 68.5 & $\mathbf{0 . 0 0 0}$ \\
\hline
\end{tabular}

Rerata kadar PIBF serum penderita abortus iminens lebih rendah yaitu $623.3 \pm 80.6 \mathrm{ng} / \mathrm{ml}$ dibandingkan dengan rerata kadar PIBF pada kehamilan normal yaitu $993.1 \pm 68.5 \mathrm{ng} / \mathrm{ml}$. Hasil analisis statistik didapatkan perbedaan bermakna rerata kadar PIBF serum kelompok penderita abortus iminens dengan kelompok kehamilan normal, hal ini dapat dilihat dari nilai $p=0,000(p<0,05)$.

\section{PEMBAHASAN}

Usia ibu dan paritas merupakan faktor risiko yang banyak diamati. Sullivan et al mendapatkan hubungan peningkatan risiko abortus spontan karena usia maternal. ${ }^{7}$ Hogge et al, menyatakan bahwa usia maternal melebihi 37 tahun secara signifikan berhubungan dengan risiko kejadian abortus spontan. Pada penelitian ini berdasarkan karakteristik usia didapatkan nilai rerata usia kelompok penderita abortus iminens $28.20 \pm 3.59$ sedangkan nilai rerata pada kelompok hamil normal didapatkan $28.87 \pm 5.52$. Hasil analisis statistik lebih lanjut, perbedaan usia pada penderita abortus iminens dengan kehamilan normal tidak memiliki perbedaan yang signifikan, hal ini terlihat dari nilai $p$ value sebesar 0.968 ( $p>0,05)$. Cunningham et al, menyatakan risiko abortus iminens meningkat sesuai jumlah kehamilan, yang berhubungan dengan usia ibu. Pada penelitian ini berdasarkan karakteristik paritas didapatkan nilai rerata gravida kelompok penderita abortus iminens setara dengan kelompok hamil normal yaitu 2,33. Hasil analisis statistik lebih lanjut, perbedaan gravida pada penderita abortus iminens dengan kehamilan normal tidak memiliki perbedaan yang bermakna, hal ini terlihat dari nilai $p$ value sebesar $1.00(p>0,05){ }^{8,9}$

Risiko abortus semakin menurun seiring dengan meningkatnya usia kehamilan. Sampel pada penelitian ini diambil usia kehamilan di atas 12 minggu dan didapatkan nilai rerata usia kehamilan kelompok penderita abortus iminens lebih tinggi yaitu $15.40 \pm$ 2.41 dibandingkan nilai rerata pada kelompok hamil normal yaitu $13.80 \pm 2.14$. Hasil analisis statistik lebih lanjut, perbedaan usia kehamilan pada penderita abortus iminens dengan kehamilan normal memiliki perbedaan yang tidak bermakna, hal ini terlihat dari nilai $p$ value sebesar $0.065(p>0,05){ }^{10}$

Riwayat abortus spontan sebelumnya menjadi faktor risiko yang perlu dipertimbangkan. Wanita yang pernah mengalami abortus spontan dikehamilan sebelumnya, memiliki risiko yang lebih tinggi untuk terjadinya abortus spontan dikehamilan berikutnya dibandingkan dengan yang tidak pernah mengalami abortus spontan. Risiko abortus pada wanita yang pernah mengalami abortus $1 x, 2 x$, dan $3 x$ adalah 11,5 - $20 \%, 28-29,4 \%$ dan $43 \%$. Riwayat abortus responden pada penelitian ini dikelompokkan menjadi ada atau tidaknya riwayat abortus, karena hanya didapatkan riwayat abortus 1 kali atau tidak pernah sama sekali. Pada penelitian ini didapatkan sebaran riwayat abortus yang sama pada kelompok abortus iminens dan hamil normal yaitu $13,3 \%$. Hasil analisis statistik lebih lanjut, proporsi riwayat abortus pada penderita abortus iminens dengan kehamilan normal tidak memiliki perbedaan yang bermakna, hal ini terlihat dari nilai $p$ sebesar $1,00(p>0,05) .{ }^{10}$

Hasil penelitian diketahui bahwa rerata kadar PIBF serum lebih rendah pada penderita abortus iminens yaitu $623,32 \mathrm{ng} / \mathrm{ml}$ dengan standar deviasi $80,59 \mathrm{ng} / \mathrm{ml}$ dibandingkan rerata kadar PIBF serum pada kehamilan normal yaitu 993,1 ng/ml dengan standar deviasi $68,53 \mathrm{ng} / \mathrm{ml}$. Hasil uji statistik didapatkan nilai $p=0,000 \quad(p<0,05)$ maka dapat disimpulkan terdapat perbedaan rerata kadar PIBF serum pada abortus iminens dan pada wanita hamil normal usia kehamilan 12-20 minggu. 
Hasil penelitian ini selaras dengan penelitian yang dilakukan oleh Polgar et al tahun 2004 yang membandingkan kadar PIBF serum pada 319 wanita hamil normal dengan 117 wanita hamil patologis. Pada kehamilan patologis (abortus iminens, partus prematurus iminens, preeklampsia, IUGR dan polihidramnion) didapatkan kadar PIBF yang lebih rendah dibandingkan kehamilan normal. ${ }^{4}$ Hasil penelitian ini didukung oleh penelitian Indanwati dan Purwaka (2013) yang menyatakan bahwa konsentrasi PIBF pada urin diukur menggunakan Enzyme-Linked Immunosorbent Assay (ELISA) dan hasilnya dalam satuan unit $\mathrm{ng} / \mathrm{ml}$. konsentrasi PIBF pada pasien dengan abortus iminens $(637,13 \pm 305,88 \mathrm{ng} / \mathrm{ml})$ lebih rendah dibandingkan kehamilan normal (991,88 \pm $97,33 \mathrm{ng} / \mathrm{ml}) \quad(\mathrm{p}=0,000)$. Hasil penelitian ini menyimpulkan bahwa wanita yang mengalami abortus iminens memiliki konsentrasi PIBF pada urin lebih rendah dibandingkan wanita dengan kehamilan normal. Hasil penelitian ini mendukung penelitianpenelitian sebelumnya yang menyatakan peran PIBF dalam mempertahankan suatu kehamilan dan keberadaan PIBF dalam darah dapat dijadikan sarana untuk mendiagnosis keadaan patologis dari kehamilan serta memprediksi luaran suatu kehamilan. ${ }^{11}$

Progesteron memerlukan mediator untuk dapat menimbulkan efek imunoendokrin pada kehamilan, yaitu PIBF yang di sintesis oleh limfosit teraktivasi yaitu sel T g/d (CD8+). Konsentrasi PIBF secara tidak langsung dipengaruhi oleh beberapa faktor yang mempengaruhi adekuat tidaknya fungsi progesteron endogen, selain itu juga dipengaruhi oleh faktor-faktor yang mempengaruhi ekspresi CD8+. Terdapat suatu hipotesis yang menyatakan bahwa fungsi progesteron dipengaruhi oleh beberapa faktor: regangan uterus, inflamasi, infeksi, perkembangan janin, dan stres baik pada ibu maupun janin. Berdasarkan pendapat tersebut, menurunnya fungsi progesteron dapat diperbaiki dengan cara mengatasi faktor penyebabnya. Sebagai contoh: stres psikologis dapat mempengaruhi konsentrasi PIBF karena sekresi Corticotropin Releasing Hormone (CRH) akan menghambat sekresi Gonadotropin Releasing Hormone (GnRH), dan glukokortikoid menghambat produksi Luteinizing Hormone oleh pituitari dan hormon-hormon produksi ovarium (estrogen dan progesteron). Sebagai akibatnya, konsentrasi progesteron endogen tidak adekuat untuk menimbulkan sintesis PIBF oleh sel T limfosit CD8+ sehingga dapat menyebabkan kegagalan suatu kehamilan. $^{12}$

Berbagai penelitian menunjukkan bahwa progesteron berperan dalam menciptakan lingkungan imun yang adekuat selama awal kehamilan. PIBF merupakan suatu mediator yang diproduksi oleh limfosit wanita hamil yang telah mengalami sensitisasi oleh progesteron. Mediator ini akan menyebabkan terjadinya toleransi terhadap antigen paternal. Toleransi terhadap kehamilan terjadi dengan meningkatkan produksi antibodi asimetris yang bersifat protektif, mempengaruhi keseimbangan sitokin Th1/Th2 serta dengan menekan aktifitas sel Natural Killer. $^{3}$

Mekanisme abortus melalui jalur imunologi berbeda dengan abortus karena kelainan kromosom. Pada abortus karena kelainan kromosom, pertautan antara pembuluh darah fetal dan maternal, yang berperan penting untuk terjadinya implantasi, tidak berkembang baik sehingga terjadi kegagalan implantasi. Dilain pihak, pada abortus melalui mekanisme imunologi, terjadi pertautan yang baik antara pembuluh darah maternal dan fetal. Namun pada perkembangan selanjutnya terjadi vaskulitis, inflamasi dan pembentukan bekuan darah yang dimediasi oleh proses imun sehingga terjadi abortus. Progesteron hanya dapat mempengaruhi abortus dari sisi imunologis ini. Jika terdapat kehamilan dengan abnormalitas kromosom yang non viabel, maka kehamilan tidak akan berlanjut hingga tahap dimana sel imunokompeten berkontak dengan janin. Imunomodulasi yang diinduksi progesteron tidak berperan dalam kasus semacam ini. ${ }^{13}$

Kelemahan pada penelitian ini yaitu tidak dilakukan pemeriksaan penunjang untuk menentukan etiologi abortus. Proses ini dilakukan hanya melalui anamnesis mengenai riwayat penyakit pasien. Pemeriksaan penunjang yang dimaksud seperti: pemeriksaan IgG dan IgM ACA untuk diagnosis Anti phospolipid syndrome; pemeriksaan TSH, T3, fT4 untuk diagnosis gangguan fungsi tiroid; pemeriksaan antinucear antibody dan anti-dsDNA untuk diagnosis lupus eritematosus sistemik. 


\section{KESIMPULAN}

Didapatkan rerata kadar PIBF serum penderita abortus iminens lebih rendah secara signifikan dibandingkan dengan kehamilan normal.

\section{DAFTAR PUSTAKA}

1. Yassaee F, Shekarriz-Foumani R, Afsari S, Fallahian $M$. The effect of progesterone suppositories on threatened abortion: A randomized clinical trial. Journal Reproduction Infertility. 2014;15(3):147-51.

2. Hudic I, Fatusic Z. Progesterone-induced blocking factor (PIBF) and Th1/Th2 cytokine in women with threatened spontaneous abortion. Journal of Perinatal Medicine. 2009;37:338-42.

3. Szekeres-Bartho J, Barakonyi A, Par G, Polgar B, Palkovics T, Szereday L. Progesterone as an immunomodulatory molecule. International Immunopharmacology. 2001;1:1037-48.

4. Polgar B, Nagy E, Miko E, Varga P, Skerez-Bartho J. Urinary progesterone-induced blocking factor concentration is related to pregnancy outcome. Biology of reproduction. 2004;71:1699-705.

5. Salomon LJ, Rozenberg P, Skerez-Bartho J, Malagrida L, Giudicelli Y, Ville Y. Change in progesterone-induced blocking factor expression rates following mifepristone administration in termination of pregnancy at 5 to 8 weeks. The Journal of Maternal-Fetal and Neonatal Medicine. 2005;17(5):353-6.

6. Kalinka J, Szekeres-Bartho J. The impact of dydrogesterone supplementation on hormonal profile and progesterone-induced blocking factor concentration in women with threatened abortion. American Journal of Reproductive Immunology. 2005;53:166-71.

7. Sullivan A, Silver R, Porter TF, et al. Fetal karyotype analysis from reccurent miscarriage patient (abstract). AJOG. 2002;187(6)

8. Hogge WA, Byrnes AL, Lanasa MC, Surti U. The clinical use of karyotyping spontaneous abortion. Am J Obstet Gynecol. 2003;189(2):397-400.

9. Cunngingham FG, Gant NF, Leveno KJ, Gilstrap LC, Hauth JC, Westrom KD. Obstetri William (terjemahan). Edisi ke-21 Vol 9. Jakarta: EGC; 2006.

10. Jacoeb TZ. Nasib kehamilan triwulan pertama: Manfaat penentuan progesteron dan antibodi antikardiolipin serum. Prosiding Simposium Temu IImiah Akbar. Jakarta: 2002:93 - 117.

11. Indanwati R, Purwaka BT. perbandingan konsentrasi progesterone-induced blocking factor (PIBF) urin pada wanita hamil usia kehamilan $<12$ minggu normal dan abortus iminen di instalasi rawat darurat dan instalasi rawat jalan RSUD Dr. Soetomo Surabaya. Majalah Obstetri dan Ginekologi Indonesia. 2013;21(1):1-6.

12. Arck PC, Rujke M, Rose M, Szekeres-Bartho J, Douglas AJ, Pritsch M, et al. Early risk factor for miscarriage: a prospective cohort study in pregnant women. Reproductive BioMedicine. 2008;17(1): 101-13.

13. Walch KT, Huber JC. Progesterone for recurrent miscarriage: truth and deceptions. Best Practice and Research Clinical Obstetrics and Gynecology. 2008;22(2):375-89. 